\title{
AGRICULTURAL BIOGAS PLANTS IN POLAND
}

\author{
Wojciech Rzeznik, Paulina Mielcarek \\ Institute of Technology and Life Sciences, Poland \\ w.rzeznik@itp.edu.pl,p.mielcarek@itp.edu.pl
}

\begin{abstract}
In Poland, for years there has been observed a growing interest in the production of energy from renewable sources, including agricultural biogas. Electricity from biogas is one of the future directions of energy development and it may be the additional source of income in rural areas. The aim of the study was to analyse the production parameters of agricultural biogas plants, present their location in Poland and determine the reduction of carbon dioxide emission obtained by producing electricity from agricultural biogas. There were 306 biogas plants in Poland, of which 96 were agricultural biogas plants. The total electric power of installed biogas plants was $235.4 \mathrm{MWe}$ in 2017 , and $43.7 \%$ represented agricultural biogas plants. The share of agricultural biogas plants in the installed electric power from renewable sources amounted to approximately $1.2 \%$. The electric power of a single biogas plant ranged from 0.08 to $2.4 \mathrm{MWe}$, on average $1.05 \mathrm{MWe}$. The largest number of agricultural biogas plants (45\%) were medium power installations (0.5-1 MWe). However, $60 \%$ of the electric power of all agricultural biogas plants was installed in objects with power over $1 \mathrm{MWe}$ (39 installations). The production of agricultural biogas was territorially diverse. The total installed electric power was from 0.8 MWe (Holy Cross) to 12.7 MWe (West Pomerania). The average electric power of biogas plant depended on the region and it varied between 0.58 MWe, for Lesser Poland, and $2 \mathrm{MWe}$ for the Opolskie Province. The production of electricity in agricultural biogas plants amounted to $437.1 \mathrm{GWh}$, in 2016. The reduction of $\mathrm{CO}_{2}$ emissions resulting from the use of agricultural biogas plants was $247 \mathrm{Gg}$, in 2016 .
\end{abstract}

Keywords: agricultural biogas plants, Poland, renewable energy, biogas.

\section{Introduction}

The share of renewable sources in electricity production is still low in Europe. However, the European Union is constantly pursuing an energy policy aimed at reducing the consumption of fossil fuels and promoting the energy production from renewable sources. Solar, wind energy and electricity production from biogas seem to be the most perspective directions of energetic development [1]. In the face of dwindling resources of coal and growing operating costs of coal power plants, also the Polish energy sector pointed out the possibility of producing electricity from biogas, especially from agricultural biogas [2]. Distributed power generation, based on renewable energy sources, could provide energy service to meet needs of the whole of Poland at an appropriate level in a continuous and natural way [3].

Nowadays, it continues to search for new ways of agriculture development in Poland. This is also reflected in undertaking a variety of economic initiatives using endogenous resources of the agricultural sector. A characteristic trend of changes in agriculture development is an increase in the importance of non-food use of feedstocks from agriculture [4]. Apart from ensuring the food security, agriculture may also perform other functions, including those associated with the energy security. Agricultural biogas plants are some chance for diversification of agriculture and multifunctional rural development [5]. Producing electricity from biogas, agriculture may be an important player among the local energy producers. In the future, the replacement of fossil fuels may lead to energy selfsufficiency in this sector.

The agricultural biogas production has also positive impact on environment, inter alia, it reduces greenhouse gas (GHG) emissions. The methane produced in biogas digesters is burned for the renewable energy production, and its combustion emits less carbon dioxide than burning conventional fuels. The level of limitation differs depending on the type of energy source replaced by biogas and the alternative use of heat produced by biogas plants [6;7]. During fermentation, nitrogen is converted to the ammonium form, which reduces the emission of nitrous oxide [8; 9]. Moreover, biogas digestate can be used in many ways, increasing positive effect of biogas production for environment. The most popular is fertilization, what limits the consumption of mineral fertilizers, the production of which requires large amounts of energy $[10 ; 11]$.

Agricultural biogas is now a small fraction of Polish energy balance. However, the importance of biogas as an energy source in Poland has been increasing year by year. It is estimated that Poland has the potential to produce biogas comparable with Germany [12]. 
The aim of the study was to analyse the production parameters of agricultural biogas plants, present their location in Poland and determine the reduction of carbon dioxide emission obtained by producing electricity from agricultural biogas.

\section{Materials and methods}

The numerical data to analyse and interpret were taken from secondary data sources, published by government departments and agencies (Table 1).

Type and source of data for analysis

Table 1

\begin{tabular}{|c|c|}
\hline Type of data & Data publisher \\
\hline $\begin{array}{l}\text { - number of biogas plants by type } \\
\text { - installed electric power } \\
\text { - electricity produced by biogas plants }\end{array}$ & $\begin{array}{l}\text { Energy Regulatory Office } \\
\text { (URE) [13] }\end{array}$ \\
\hline $\begin{array}{l}\text { - location of agricultural biogas plants } \\
\text { - number of agricultural biogas plants } \\
\text { - installed electric power }\end{array}$ & $\begin{array}{l}\text { National Support Centre for Agriculture } \\
\text { (KOWR) [14] }\end{array}$ \\
\hline - $\mathrm{CO}_{2}$ emission factors & $\begin{array}{c}\text { The National Centre For Emissions } \\
\text { Management } \\
\text { (KOBIZE) [15] }\end{array}$ \\
\hline
\end{tabular}

The collected data were used to elaborate the power structure of agricultural biogas plants. The thematic map illustrating the regional diversity in installed electric power was made basing on the same information. It also presents the share of electric power of agricultural biogas plants in renewable sources and in total biogas power. Data about the installed electric power and the number of biogas plants are a state of September 2017. The amount of energy is the production for 2016.

The amount of avoided $\mathrm{CO}_{2}$ emission by producing electricity in agricultural biogas plants was calculated using the $\mathrm{CO}_{2}$ emission factors: $806 \mathrm{~kg} \mathrm{CO}_{2} \cdot \mathrm{MWh}^{-1}$ for electricity production in Poland and $240 \mathrm{~kg} \mathrm{CO}_{2} \cdot \mathrm{MWh}^{-1}$ for electricity production from biogas $[15 ; 16]$.

\section{Results and discussion}

For the years following there was dynamic development of the sector of renewable energy production. In Poland, the total electric power of installations for renewable energy production was 8538.3 MWe in 2017. One of the most dynamically developing renewable sources is biogas production. The total electric power of biogas plants was $235.4 \mathrm{MWe}$, and it was $43.7 \%$ of this power that represents agricultural biogas plants. Their share in the total installed electric power of renewable sources was about $1.2 \%$ (Figure 1).

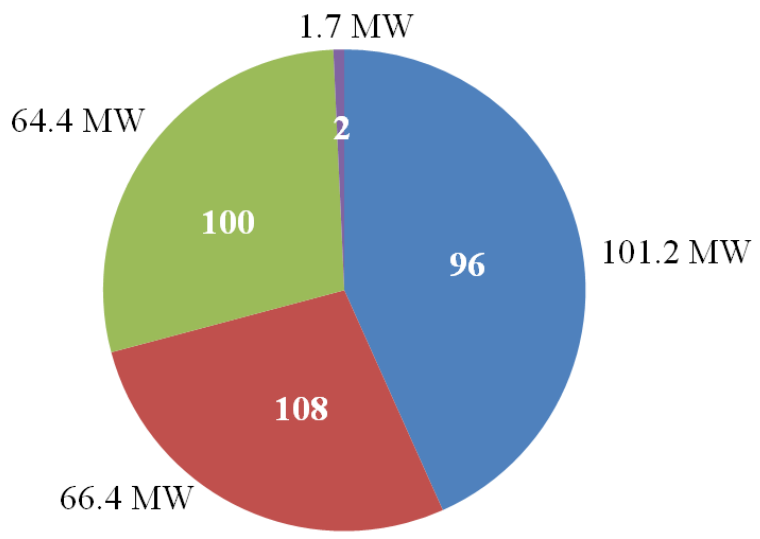
- Agricultural biogas plants
- Landfill biogas plants
- Sewage biogas plants
- Other biogas plants

Fig. 1. Biogas plants in Poland - number and electric power (own study based on [13]) 
Figure 2 presents the structure of electric power installed in agricultural biogas plants in Poland. The average electric power of Polish biogas plants was $1.05 \mathrm{MWe}$. The smallest of them had 0.08 MWe (Zielona, Masovia Province), and the largest one 2.4 MWe (Darżyno, Pomerania Province and Koczergi, Lublin Province).

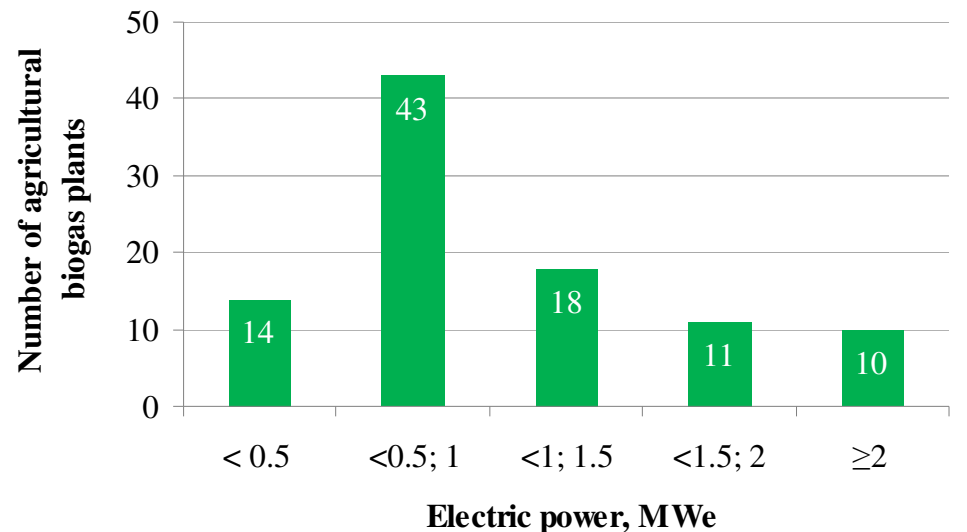

Fig. 2. Structure of installed electric power of agricultural biogas plants in Poland (own study based on $[13 ; 14]$ )

The most of agricultural biogas plants (about $45 \%$ ) were medium-sized with electric power from 0.5 to $1 \mathrm{MWe}$. Their number was similar to the number of biogas plants with power above $1 \mathrm{MWe}-$ 39 plants. The power installed in these objects was $60 \%$ of all agricultural biogas plants. There were very few small biogas plants $(P<0.5 \mathrm{MWe})$, and among of them only two were micro-biogas plant $(P<0.1 \mathrm{MWe})$. Nevertheless, it seems that the number of micro-biogas plants should increase, especially in the livestock farms, where the produced electricity and heat may be used for their own needs. The main stimulant of agricultural micro-biogas plant development in Poland is the availability of funds for co-financing these investments under the Regional Operational Programmes 2014-2020 and the legal regulations promoting for micro-installations (Figure 2).

The agricultural biogas production is territorially diverse. The total installed electric power is from 0.8 MWe for the Holy Cross Province to $12.7 \mathrm{MWe}$ for the West Pomerania. The average electric power of biogas plants depended on the region and varied between $0.58 \mathrm{MWe}$ (Lesser Poland) and 2 MWe (Opole Province), (Table 2).

Table 2

Regional structure of agricultural biogas plants in Poland (own study based on [13; 14])

\begin{tabular}{|c|c|c|c|}
\hline Province (Voivodship) & $\begin{array}{c}\text { Total electric power, } \\
\text { MWe }\end{array}$ & $\begin{array}{c}\text { Number of biogas } \\
\text { plants }\end{array}$ & $\begin{array}{c}\text { Average power } \\
\text { of biogas plant, } \\
\text { MWe }\end{array}$ \\
\hline Lower Silesia & 9.52 & 9 & 1.06 \\
\hline Kuyavia-Pomerania & 7.99 & 6 & 1.33 \\
\hline Lublin & 9.86 & 7 & 1.41 \\
\hline Lubusz & 2.79 & 4 & 0.70 \\
\hline Lodzkie & 5.06 & 4 & 1.27 \\
\hline Lesser Poland & 1.15 & 2 & 0.58 \\
\hline Masovia & 4.9 & 5 & 0.98 \\
\hline Opole & 2 & 1 & 2.00 \\
\hline Subcarpathia & 2.5 & 3 & 0.83 \\
\hline Podlaskie & 7.6 & 9 & 0.84 \\
\hline Pomerania & 12.16 & 9 & 1.35 \\
\hline Silesia & 2.06 & 3 & 0.69 \\
\hline Holy Cross & 0.8 & 1 & 0.80 \\
\hline Warmia-Masuria & 9.46 & 10 & 0.95 \\
\hline Greater Poland & 10.67 & 10 & 1.07 \\
\hline West Pomerania & 12.69 & 13 & 0.98 \\
\hline
\end{tabular}


The largest electric power was installed in the north of Poland. The location of biogas plants in these regions stems not only from the size of agricultural production, but also from the structure of the farms. There are many large commercial family farms and agricultural companies. As much as $30 \%$ of the installed power in Pomeranian and West Pomeranian agricultural biogas plants belongs to one owner - Poldanor S.A. The small installed power of agricultural biogas plants is mainly in the southeastern part of the country. It is related to low agricultural production and farm fragmentation. In central Poland, there were regions (Masovia, Kuyavia-Pomerania and Lodzkie Province), where the installed electric power is on an average level. These areas have a great potential, which is associated with quite large crop and animal production. However, in these regions, there is a small number of large-scale farms, and small private farms dominate, what is not good for the development of agricultural biogas production. With appropriate co-financing and ongoing land consolidation, it should expect to increase agricultural biogas production in the near future (Figure 3).

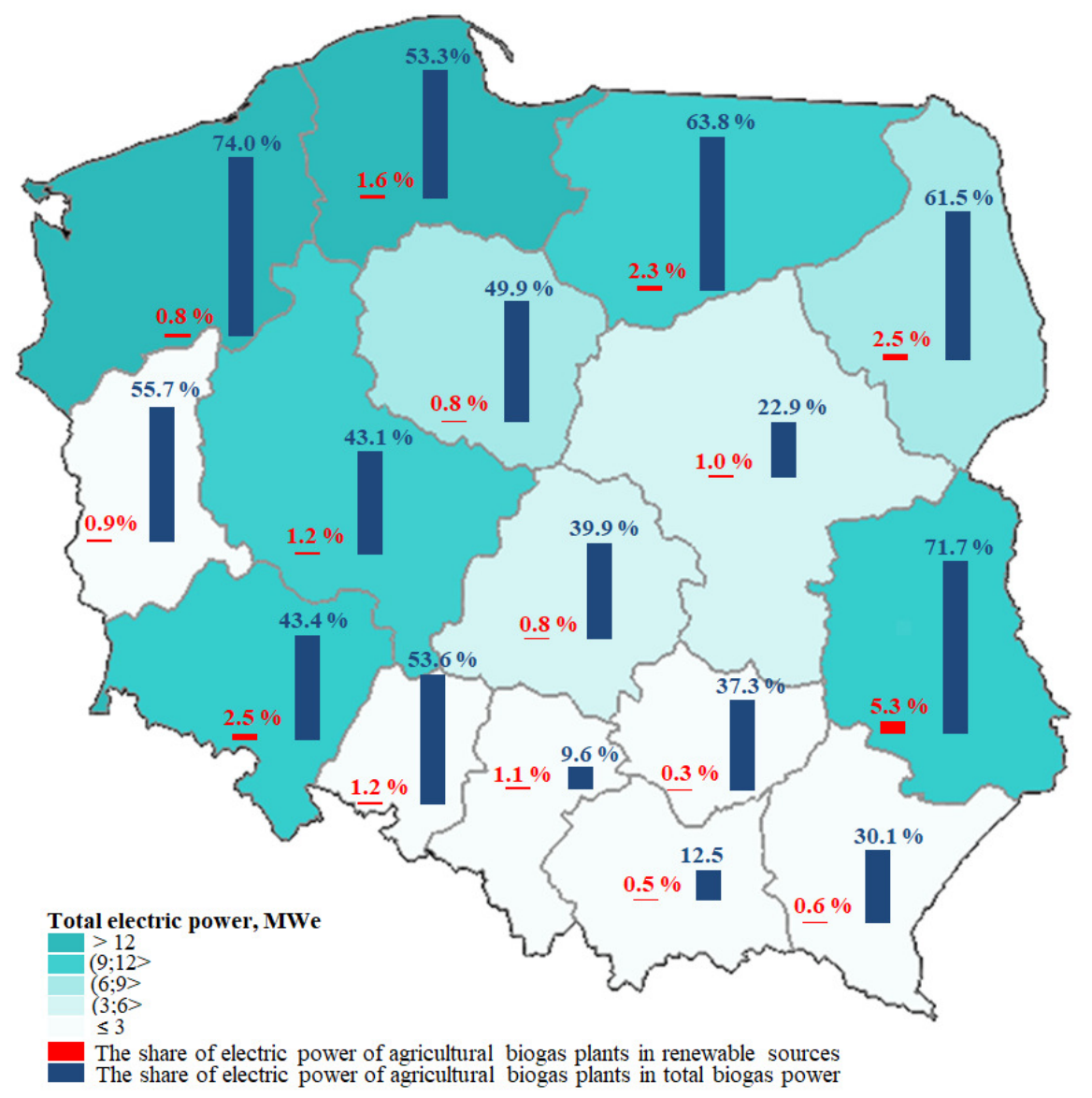

Fig. 3. Electric power of agricultural biogas plants in Poland and share of agricultural biogas electric power in total power of biogas plants and in renewable sources

The smallest share of agricultural biogas plants is in Silesia, because it is an industrial area with the highest rate of urbanization in Poland. The largest share was noted in the Lublin Province $(71.2 \%)$ and the West Pomerania Province (74\%), where the agricultural production is on an average level (Figure 3).

According to the latest data on electricity production, in 2016 year, 20.1 TWh of energy was produced in renewable energy installations, which was $13.7 \%$ of total production. The share of electricity from the combustion of agricultural biogas represented $2.2 \%(437.1 \mathrm{GWh})$ of electricity from renewable sources [13; 17]. The value of avoided $\mathrm{CO}_{2}$ emission calculated on the basis of emission factors was $247 \mathrm{Gg} \cdot$ year $^{-1}$. This calculation does not take into account the environmental benefits resulting from $\mathrm{CO}_{2}$ absorption by plants used as substrates for biogas production, reduction of harmful gas emissions caused by biogas digestate fertilizing and use of heat generated in a biogas plant. 


\section{Conclusions}

1. The total installed electric power of the biogas plants was $235.4 \mathrm{MWe}$, and $43.7 \%$ represented agricultural biogas plants. The share of agricultural biogas plants in the installed electric power from renewable sources amounted to $1.2 \%$.

2. The average electric power of biogas plants was $1.05 \mathrm{MWe}$ and ranged from 0.08 to $2.4 \mathrm{MWe}$. The largest number of agricultural biogas plants $(45 \%)$ were medium power installations $(0.5$ $1 \mathrm{MWe}$ ). However, $60 \%$ of the electric power of agricultural biogas plants was installed in objects with power over $1 \mathrm{MWe}$ (39 installations).

3. The agricultural biogas production was territorially diverse. The total installed electric power was from 0.8 MWe (Holy Cross) to $12.7 \mathrm{MWe}$ (West Pomerania). The average electric power of biogas plants depended on the region and it varied between 0.58 MWe (Lesser Poland), and 2 MWe (Opole Province).

4. The electricity produced in Polish agricultural biogas plants was to $437.1 \mathrm{GWh}$, in 2016 . The reduction of $\mathrm{CO}_{2}$ emission resulting from the use of agricultural biogas plants was $247 \mathrm{Gg}$, in 2016.

\section{Acknowledgements}

The work is co-financed by the Ministry of Agriculture and Rural Development and carried under the Multiannual Program for the years 2016-2020 "Technological and environmental projects for innovative, effective and low-emission economy in rural areas".

\section{References}

[1] Torrijos M. State of Development of Biogas Production in Europe. Procedia Environmental Sciences, vol. 35, 2016, pp. 881-889.

[2] Igliński B., Buczkowski R., Iglińska A., Cichosz M., Piechota G., Kujawski W. Agricultural biogas plants in Poland: investment process, economic and environmental aspects, biogas potential. Renewable and Sustainable Energy Reviews, vol. 16, no 7, 2012, pp. 2890-2900.

[3] Igliński B., Buczkowski R., Cichosz M. Biogas production in Poland - Current state, potential and perspectives, Renewable and Sustainable Energy Reviews, vol. 50, 2015, pp. 686-695.

[4] White E.M., Latta G., Alig R.J., Skog K.E., Adams D.M. Biomass production from the U.S. forest and agriculture sectors in support of a renewable electricity standard, Energy Policy, vol. 58, 2013, pp. 64-74

[5] Chodkowska-Miszczuk J., Szymańska D. Agricultural biogas plants - A chance for diversification of agriculture in Poland, Renewable and Sustainable Energy Reviews, vol. 20, 2013, pp. 514-518.

[6] Borjesson P., Berglund M. Environmental systems analysis of biogas systems - Part II: The environmental impact of replacing various reference systems. Biomass Bioenergy, vol. 31, no. 5, 2007, pp. 326-344.

[7] Pucker J., Jungmeier G., Siegl S., Poetsch E.M. Anaerobic digestion of agricultural and other substrates - implications for greenhouse gas emissions. Animal, vol. 7, 2013, pp. 283-291.

[8] Vorbrodt-Strzałka K., Pikon K. Environmental impacts associated with production and utilization of agricultural biogas. Archives of Waste Management and Environmental Protection, vol. 15, no. 4, 2013, pp. 1-12.

[9] Clemens J., Trimborn M., Weiland P., Amon B. Mitigation of greenhouse gas emissions by anaerobic digestion of cattle slurry. Agriculture. Ecosystem and Environment, vol. 112, 2006, pp. 171-177.

[10] Alburquerque J.A., de la Fuente C., Ferrer-Costa A., Carrasco L., Cegarra J., Abad M, Bernal, M.P. Assessment of the fertiliser potential of digestates from farm and agroindustrial residues. Biomass Bioenergy, vol. 40, 2012, pp. 181-189.

[11]Bartkowiak A., Jadczyszyn T., Mac J., Matros B., Matyka M., Mielcarek P., Rzeźnik W., Stekla J., Talarczyk W., Zbytek Z., Witorożec A. Różne aspekty wykorzystania biomasy pofermentacyjnej (Different aspects of the use of biogas digestate.) Eds. W. Rzeźnik. FalentyPoznań: ITP, 2017. 109 p. [In Polish]. 
[12] Budzianowski W.M., Chasiak I. The expansion of biogas power plants in Germany during the 2001-2010 decade: Main sustainable conclusions for Poland. Journal of Power Technologies, vol. 91, 2011, pp. 102-113.

[13] URE-Urząd Regulacji Energetyki. (Energy Regulatory Office). (In Polish). [online] [12.12.2017]. Available at: https://www.ure.gov.pl/uremapoze/mapa.html.

[14] KOWR-Krajowy Ośrodek Wsparcia Rolnictwa. Rejestr wytwórców biogazu rolniczego (National Support Centre for Agriculture. Register of energy companies producing agricultural biogas). (In Polish). [online] [12.12.2017]. Available at: http://www.kowr.gov.pl/interwencja/odnawialnezrodla-energii/biogaz-rolniczy/wytworcy-biogazu-rolniczego/rejestr-wytworcow-biogazurolniczego.

[15] KOBIZE. Wartości opałowe (WO) i wskaźniki emisji $\mathrm{CO}_{2}$ (WE) w roku 2013 do raportowania w ramach Wspólnotowego Systemu Handlu Uprawnieniami do Emisji za rok 2016 (Calorific values $(\mathrm{CV})$ and $\mathrm{CO}_{2}$ emission factors (EF) in 2013 for reporting under the Community Emissions Trading Scheme for 2016). (In Polish). [online] [12.12.2017]. Available at: http://www.kobize.pl/uploads/materialy/materialy_do_pobrania/monitorowanie_raportowanie_we ryfikacja_emisji_w_eu_ets/WO_i_WE_do_stosowania_w_SHE_2016.pdf.

[16] KOBIZE. Wskaźniki emisyjności $\mathrm{CO}_{2}, \mathrm{SO}_{2}, \mathrm{NO}_{\mathrm{x}}, \mathrm{CO}$ i pyłu całkowitego dla energii elektrycznej. (Emission factors for $\mathrm{CO}_{2}, \mathrm{SO}_{2}, \mathrm{NO}_{\mathrm{x}}, \mathrm{CO}$ and total dust for electricity). (In Polish). [online] [10.02.2018]. Available at:

http://www.kobize.pl/uploads/materialy/materialy_do_pobrania/wskazniki_emisyjnosci/180108_ wskazniki_spalanie_na_mwh.pdf.

[17] GUS - Główny Urząd Statystyczny. (Statistic Poland). (In Polish). [online] [19.12.2017]. Available at: http://stat.gov.pl/. 